\title{
THE MOST CRITICAL ISSUES FACING MANAGERS IN SOUTH AFRICA TODAY
}

\author{
G MARITZ (Anglogold Ltd)
}

South African managers today find themselves squeezed between juxtapositions, such as international competition and simultaneous skill development programmes to combat illiteracy. A second example is high unemployment and the concurrent shortage of IT specialists. Affirmative action has led to troublesome labour relations. HIVIAIDS has an enormous impact on business and must be managed. South African managers need to change their managerial approaches to cope with the increasing demands of this country. Managers must be aware of the realities facing them and know how to turn them into potential growth opportunities for their organisations and South Africa as a country.

Keywords: management waves, unemployment, education, affirmative action, Aids

\section{INTRODUCTION}

Managers in present day South Africa are faced with unique challenges, typical of only this country. South Africa is located at a reasonable geographic distance from first world countries, has a richly diverse culture and is undergoing a period of economic instability. A bridge between first and third world elements exists in the country. South Africa is a developing nation under careful international scrutiny and immense pressure.

The purpose of this paper is to highlight the most significant problems facing South African managers in the new millennium. Some of these challenges include technology, exhaustible natural resources, crime, globalisation, work ethics, affirmative action and emigration. The detrimental impact of HIV/AIDS also has to be taken into consideration. Other than those mentioned above, many other challenges face South African managers. Unfortunately, they cannot all be discussed. Those that have been selected and expanded on have only been discussed in brief, due to the limit in length of this paper. Enough information, however, is available to have completed a conference paper on every individual aspect. The information in this paper, therefore, is brief and to the point.

Local and international literature, including textbooks, articles and previous research, was consulted. Furthermore, personal interviews were held with business practitioners and academics, as well as managers in various fields. Observation and personal experience were also included in the research.

Various ways of coping with the most obvious challenges are examined. Proactive planning by management must replace reactive ways of management. It is time for managers to move on to fourth and fifth wave management in a country where many organisations, such as the civil service, clench to second wave managerial approaches.

Information technology must be implemented throughout the entire workforce. Human resource development is imperative. Education by means of practical skills training is a method in which the potential workforce can be uplifted. Educational sponsorships by able 
companies form only one way of facing social responsibility and meeting one of the needs of society at large.

\section{THE ROLE OF MANAGERS}

A manager can be defined as a person who allocates human, material and information resources in pursuit of an organisation's goals (Hellriegel et al. 1999:7). A strategic manager is defined as a manager who is responsible for the overall direction and operations of an organisation (Hellriegel et al. 1999:14). The goals of any organisation are success-driven, and therefore it can be stated that managers have the role of leading their organisations to success.

The measurement of success is binary in nature. Firstly, and according to the laws of business, organisations must achieve profitability. Sustainable profitability on the long-term is the main driver of any organisation. This can be referred to as the business in business. The second part of success measurement is the degree to which success is attained on a human level. This can be referred to as humanity in business.

Business ethics concerns itself with how humans act while conducting a business. This implies the motivation behind the decisions made that affect business (Bennett-Alexander et al. 1996:98). The most powerful argument for ethics in business is success. In South Africa it is in the best interest of managers to lead their companies to success in an ethical manner. The challenges facing South African managers discussed in this paper testify to this fact.

\section{THE NECESSITY OF CHANGE}

South Africa is ranked $25^{\text {th }}$ in the micro-economic factor section of the 2000 Global Competitiveness Report (Bennett 2000:6). Management guru Michael Porter states that South Africa's productive capacity is way beyond that reflected in its GDP per capita as a result of low productivity levels. Porter further states that wealth is created in the microeconomic level and only this will improve standards of living (Bennett, 2000:6). Growth is a result of increased productivity, which is a result of best practice and good strategy.

A challenge facing managers is that of change. Many companies and people resist change due to fear of leaving their comfort zones. Satisfaction with the status quo greatly conflicts with a successful managerial process, since the term process in itself implies dynamic change. Organisations, therefore, cannot perform optimally by clenching firmly onto static managerial approaches. Businesses in South Africa have to create something completely new and be more creative to liberate themselves from second and third wave characteristics and move on to become fourth and fifth wave organisations. The waves of change must be seen as opportunities for creating a new and brighter future for South Africa (Kruger 1995:1).

\section{Second wave management}

Second wave management is characterised by autocracy, bureaucracy, hierarchical structures with standardisation and restraint by rules and regulations (Timmers 1996:48-49). A search for order, security and stability is the order of the day. Standardisation is aimed at 
production, task procedures and salary scales. Second wave organisations are collections of interdependent elements directly affected by the external environment. Needless to say, employee satisfaction and personal commitment is not very high. Managers are the prime decision-makers and do not include employee input. Sadly, there are still companies in South Africa, such as the civil service, that operate in this manner. Second wave management is archaic.

\section{Third wave management}

Companies that have realised the outdated nature of second wave management have adapted their organisations to fit the circumstances best suited to them (Timmers 1996:52). Many of those companies have adopted third wave management principles. In 1995 it was stated that companies in South Africa were at the forefront of the development of third wave management (Kruger 1995:1).

In third wave management, a climate of creativity, innovation and adaptability is created. Entrepreneurship involves the ability to recognise opportunities and take risks. The strength of third wave companies lies in the ability to transform products and organisations in response to changes in the economy, social habits and customer interests. Managers act as coaches, facilitators, servants and advocates (Timmers 1996:60).

\section{Fourth wave management}

Whereas third wave management styles respond to change, fourth wave management styles anticipate change. The purpose of doing business is wider than in third wave management. Strategic planning focuses on leaving a valuable legacy for the future, and businesses are viewed as a means to gain personal fulfilment and serve others. The role of management is basically nonexistent. It is viewed as shifting from wanting to beat the competition to wanting to serve the world. A few South African companies have adopted this approach, to their benefit.

Fourth wave corporations are democratic, participatory, have shared vision, focus on the customer, and apply co-creation, equality and maximum flexibility. Successful fourth wave organisations have an absence of hierarchy without any management levels. The roles of leader and follower are dictated by situational needs. Work and family life are integrated, and a deep level of trust is maintained. The entire fourth wave corporation is a lifelong learning organisation, continually striving for excellence.

An emerging issue in South Africa is the need for a balance between a company's business growth objectives and the demand for environmentally responsible actions. South African managers have come under increasingly sharp criticism for allowing a lack of competitiveness to erode their market position (Kruger 1995:21).

It is the task of management to realise that honest and open organisational climates form the only way to move forward and obtain the necessary consciousness to successfully implement and manage change. By progressing, organisations can improve their productivity and, according to Porter, their competitiveness (Bennett 2000:6). 


\section{GLOBALISATION}

Globalisation of companies is an international trend that is also evident in South Africa. The presence of companies such as the "Big Five" accounting firms and strategic consulting firms testify to this fact. International business has forged a network of global linkages around the world (Czinkota et al. 1999:7). Communication, transportation and technology have decreased the size of the world and are placing pressure on South African companies to remain with the "international pack" while largely being hampered by the work force and other typically South African problems.

It is attainable for South African employees in international companies to ask for transfers to branches of the company in another country. Therefore, turnover in key management personnel due to emigration, also faces South African managers. Many competent employees seek greater opportunities in foreign work markets and leave South Africa in search of a more stable political and economic future. The weak state of the Rand over the long term and the high taxation of top earners result in the fact that it is financially more viable to earn money in a foreign currency than in the local one.

\section{TECHNOLOGY}

The gap between the first world countries and South Africa as a developing nation is especially evident on the technological front where it is a necessity for survival for managers to not only keep abreast with the latest technological trends, but also to anticipate them.

International schools of thought emphasise a proactive and not reactive approach to technology. For managers to adopt this attitude in South Africa implies the ability to compete in the international markets, but the implementation thereof in the South African workforce is complex. Efficient implementation of information technology requires it throughout the entire workforce, not only on strategic level.

Urgent action by both government and the information technology (IT) industry is needed to address the IT skills shortage in South Africa. A report by the International Data Corporation (IDC) forecasts that there will be a shortage of 53000 skilled workers in the South African IT industry by 2003 (Sigonyela 2000:2). The report covers eleven other emerging markets and ranks South Africa last. According to the IDC, the Internet will enable small to medium-sized enterprises to compete with big business on a global scale. It is therefore essential for South Africa, with approximately 55 percent of its businesses in this category, that the necessary skills are made available so that the country can compete effectively in the global digital economy (Sigonyela 2000:2).

South African companies have to have active in-house training suited to their operational requirements. Cisco Systems, one of the world's major networking devices producers, has its own networking academy. Unlike traditional IT training institutions, the academy does not only focus on recruiting graduates with mathematics, but trains anyone who has the required aptitude for a career in IT. Other companies with commercial training academies include PQ Africa, Dimension Data and Microsoft SA. Although such companies should be applauded, there are not enough of them to fulfil the future IT demands of this country if it is to effectively compete on a global scale. 
Another challenge is that the shortage of IT specialists in developed countries will result in "brain drain" in South Africa. Interviews with final year IT students showed a large interest in emigration to countries with more promising futures than are presently available to them in South Africa. Clem Sunter (2000:30) states that a threat of the present postmodernist society is that the younger generation is more individualistic than previous generations. This means that they soon become frustrated with bureaucracy and require space to be entrepreneurs.

South African IT organisations must create an environment in which high flyers are never bored. World-class companies, as Sunter (2000:31) refers to them, grant employees a genuine stake in the business, usually by way of share options, virtually straightaway. Since this feature is very attractive, companies should approach potential (highly talented) employees and offer them a good packet. The incredible shortage in IT specialists allows those individuals with the latest knowledge and skills to choose where they want to work.

\section{UNEMPLOYMENT}

The irony in this situation is that although there is such a great demand for information technology specialists, South Africa has a current unemployment rate of approximately thirty percent, according to Standard Bank Group Economist Iraj Abedian (Paton 2000:1). Even those with degrees are poorly skilled. To remain at the top, professionals must constantly reinvent themselves.

About one million formal sector jobs have been lost since 1994. Recent figures from Statistics SA (Paton 2000:1) show that in the past two years, though jobs continued to be shed by the formal sector, employment as a whole remained constant. This is attributed to growing part-time, or casual workers. In developed economies, technology has allowed highly skilled professionals to leave full-time employment and work as contractors from home, often bringing improvements to their lifestyle.

However, technological developments in South Africa are not as high as required, and therefore the growing casual labour force consists of unwilling part-time employees. Parttime workers will be at a disadvantage because they will not have benefits such as pension or provident funds. Households will have to make up these costs and the State will continue to feel the effect of the low or no private savings.

Jobs are, however, are being created by some. Women-owned businesses are becoming the fastest growing employers (Succeed 2000: 3). A recent survey referred to in this article 1995 to $27,6 \%$ in 1998 . According to the survey, this can be attributed to several factors. The first is that women are generally better at getting a group of people to work together towards a common goal. The second is that women welcome diversity in the work environment more than men. Thirdly, in the work environment women tend to share profits with their employees earlier than men.

A new economy is driving companies to provide better services due to the Internet and electronic commerce. In South Africa, however, the technological jobs that are being created are not suited to casual workers. This is why individuals have to constantly reinvent 
themselves. Globally competitive export industries, as vital as they are for bringing South Africa into the new economy, will not create jobs in the numbers needed. Training, skills development and job creation are therefore still high on the priority list of South African managers if the economy is to improve as a whole.

\section{EDUCATION}

While encouraging international ties, South African managers find themselves in a country where a large amount of the workforce is illiterate. More than half the people entering the South African workforce come from school systems that have not adequately prepared them with the skills they need to advance within organisations. Intensive human resource development is required by means of education and practical training to equip these labourers with the skills they need in order for their development and that of society at large.

Minister of Education Kader Asmal stated at the annual report meeting of the Joint Education Trust (JET) that learning must lead to employment if a better life for all is to be achieved (SUCCEED 2000:1). South Africa has to develop the range of skills necessary to compete in the global economy and provide for the enormous developmental needs of society. Minister Asmal has called on non-government organisation (NGO) sectors to work with the Department of Education in supporting his Tirisano (working together) plan, which was launched in January 2000. The plan deals with five issues including HIV/AIDS, school effectiveness and educator professionalism, literacy, further and higher education, and organisational effectiveness of the national provincial departments. Minister Asmal further stated that "the two non-negotiables for any citizen to be successful in the future are economic literacy and technological literacy". Before this can be achieved, however, the population must be able to read and write. Companies should, in the best interests of the country, investigate the possibility of introducing literacy programmes or other skills development programmes.

Furthermore, work ethics have to be installed in workers. There is constant friction in managers concerning the juxtaposition of employee demands and inflation. Dissatisfaction amongst labourers gives rise to strikes in the hope of enforcing wage increases. Strikes, in turn, halt productivity and this is detrimental to the pursuit of increased profitability. Employees must be kept satisfied in a financially viable manner.

Another great challenge is the diversity of the South African workforce. Since the official abolition of Apartheid on 2 February 1990, the workforce has become increasingly less white and the role of gender equality has grown in significance. The consequence of this fact is that many white, middle-aged, male managers in South Africa have lost their jobs in a paradoxical attempt at job creation.

\section{AFFIRMATIVE ACTION}

The aim of affirmative action is clearly highlighted in Nelson Mandela's opening address to the African National Congress (ANC) in his capacity as President of the ANC in Port Elizabeth in October 1991 (Dixon 1994:iii). It is important to note that the statement was 
made two and a half years before he became President of the Republic of South Africa. In this address, he stated:

"The primary aims of affirmative action must be to redress the imbalances created by apartheid... We are not... asking for handouts from anyone. Nor are we saying that just as a white skin was a passport to privilege in the past, so a black skin should be the basis of privilege in the future... The special measures that we envisage to overcome the legacy of post discrimination, are not intended to ensure the advancement of unqualified persons, but to see to it that those who have been denied access to qualifications in the past can become qualified now, and that those who have been qualified all along but overlooked because of past discrimination, are at last given their due... The first point to be made is that affirmative action must be rooted in principles of justice and equity" (Dixon 1994:iii).

However, affirmative action has unfortunately led to tokenism in a large degree, resulting that managers are in control of subordinates who are unable to perform their work according to the required standards of the organisation. Informal and institutional discrimination is strengthened as a result and it is the role of the manager to keep the organisational climate comfortable.

Affirmative action has various pitfalls (De Klerk 1996:238). What is meant by affirmative action is that when two people have the same merit, the non-white person should be chosen over the white person. The first pitfall created thus is that a quota system does more harm than good. In the USA, for example, it proved counterproductive since it attacked the selfesteem of blacks. Secondly, affirmative action may never forfeit standards and merit. Lowered standards will harm the entire population. Thirdly, affirmative action must always bear an educational character. While compensating for the perceived lack of justice, it must make people self-confident and self-supportive. It may never be born from a selfish egocentrism, but rather out of conviction.

The dissatisfaction of employees leads to uncomfortable labour relations and an eventual disadvantage to overall productivity of the business. Costs then have to be reduced, and downsizing is an obvious result. The unemployment rate increases in this manner.

Work ethic has to be installed in workers. It is demoralising to read in Enterprise (September 2000:60), a magazine "where black business lives", that George Molebatsi writes that there are no previously disadvantaged workers, only the continuously disadvantaged. He calls for amendments to the Labour Relations Act (Act 66 of 1995) that must be aimed at equitable redistribution of wealth and a restoration of the dignity of labour. In other words, an enabling environment must be created that will make it possible for labour to challenge any form of injustice at the workplace, in the form of capital. In this regard, the managerial approach of shared vision and employee involvement at all possible levels cannot be emphasised enough. If employees feel a personal commitment to striving towards goals they personally helped develop, their belief in the organisation will be internalised, and productivity improved.

\section{AIDS}

Unfortunately, the HIV/AIDS epidemic is one that will affect everybody in the workplace, whether they are infected or not (Succeed 2000:6). The epidemic is spreading like wildfire. 
Statistics provided by UNAids (Swanepoel 2000:9) show that almost one fifth of the total South African population is HIV positive. The number of South Africans dying before the age of fifty has almost doubled over the past ten years, despite better access to healthcare and an improved standard of living of most South Africans since 1990.

Information supplied by the Metropolitan Employee Benefits (Whiteside \& Sunter 2000:15) predicts that the number of HIV-positive people in South Africa between the ages of 15 and 59 will rise from some 3,5 million currently to over 5,5 million by 2010 . Full blown AIDS cases in the same age group, currently at 180 000, will rise to 700000 . Average life expectancy will drop from the current 48 years for women to 32, and from 52 for men to 36 . By 2005, nearly 1 million children will lose their mothers to AIDS (Whiteside \& Sunter $2000: 15)$. In the following five years, the figure will have doubled to 2 million.

AIDS is killing people in the economically active age group (Whiteside \& Sunter 2000:15). According to lan Harebottle (Succeed 2000:5), a top strategic business consultant specialising in HIV/AIDS, the reality is even more worrying than the statistics convey. The phenomenal increase in AIDS will change markets dramatically. Many families will lose their breadwinners, resulting in less money to spend. Spending patterns will switch from luxury goods to healthcare products. Death and loss of disposable income also means that companies will no longer be able to sell on credit into high-risk marketplaces.

President Thabo Mbeki stated in his opening address of the $13^{\text {th }}$ International AIDS Congress held in July 2000 in Durban, that extreme poverty is the cause of the spread of AIDS (Steyn 2000:12). AIDS must be fought, however, to relieve poverty in this country. A report by the World Bank (Taitz 2000:1) states that lower economic growth and increasing poverty has a snowball effect, in which HIV/AIDS impoverishes families, and this impoverishment increases the spread of the virus.

Such a snowball effect can only be stopped by greater investments in the effective prevention of AIDS and the upliftment of poverty. The amount of money spent by companies as a result of AIDS is horrific. An estimated R 7,2 billion was spent on educating those of a productive age who died of AIDS in 1999 to 2000. A study by ING Barings (Taitz 2000:1) estimates that by $2003,12 \%$ of highly skilled workers, $20 \%$ of skilled workers and $27,2 \%$ of low-skilled workers will be infected. It will cost an estimated R 250000 to replace each skilled labourer lost. Eskom estimates that it will spend R 400 million a year on pensions, medical aid, lost productivity and the recruitment of new workers from 2005 onwards.

The impact on business is titanic. Research conducted by Metropolitan Employee Benefits (Whiteside \& Sunter 2000:4) concluded that a company with one thousand employees could save about $R 10$ million in indirect costs over a ten year period by spending $R 100000$ upfront and a further R 25000 a year on an AIDS intervention programme.

A high turnover of workers will mean an increase in factory accidents and injuries because of a less experienced workforce and the side effects of the disease, both physical and psychological. Employee morale will also be affected by the death of co-workers and work team disintegration (Whiteside \& Sunter 2000: 4). Employee benefits will cost more, as payouts for pension funds, provident funds, death benefits, life insurance and funeral assistance schemes increase. Harebottle (Whiteside \& Sunter 2000:4) states that the issue of employee confidentiality will also cost the company. Not only will there be industrial 
relations issues to negotiate, but also litigation costs if confidentiality is breached. The result will be a decrease in productivity and a further increase in costs.

It is in the best interest of each company to formulate an AIDS programme including an impact assessment and plan of action, which must include policy development and education. Various steps can be taken to do this. Firstly, the number of infected workers must be estimated. This can be done by voluntary blood or saliva testing. Secondly, the impact of AIDS on healthcare and benefit schemes must be assessed, since costs can become unbearably high for both the company and employee. Thirdly, the impact of the disease on productivity must be established. Companies need to establish what the key operations are and which positions are critical to maintaining them, what the cost of replacing employees will be, and what effect frequent bereavements will have on employee morale (Whiteside \& Sunter 2000:4).

An AIDS policy provides a framework and a guide for an AIDS programme, ensures that both employers and employees know that discrimination is taboo, and ensures that infected employees are treated consistently. The policy should be developed in consultation with all interested parties and based on current medical and scientific knowledge, as well as legal requirements (Whiteside \& Sunter 2000:4).

Jim Murphy of Barlow Ltd (Murphy 2000:21) claims that foreign investors are more concerned about AIDS than crime. Management has to be prepared, know what to expect and prepare the workplace accordingly. In every business an understanding of both the physical and psychological aspects of HIV/AIDS goes a long way to ensure a safe and supportive workplace for all.

\section{CLOSURE}

The above discussion indicates the unique nature of being a manager in South Africa. Not only are managers faced with challenges, but they also have the exceptional task of building bridges across diverse cultures while faced with trying economic and political issues.

The situation is not negative, it is challenging. Managers cannot look to overseas counterparts for solutions, since South Africa's problems are largely unique. South African managers have the incomparably interesting and challenging assignment of adding colour to the potentially bleak canvas of the country's future. We already have the equipment to create a masterpiece for the rest of the world to marvel at. Perhaps this should be part of our shared vision.

\section{BIBLIOGRAPHY}

BENNETT J. 2000. SA's unfulfilled potential. Sunday Times, July 9: 6 .

BENNET -ALEXANDER DD, HARRISON LF \& HASS ME. 1996. The legal, ethical and regulatory environment of business. Cincinnati: South Western.

CZINKOTA MR, RONKAINEN IA \& MOFFETT MH. 1999. Intemational Business. Fort Worth: Harcourt Brace. 
DE KLERK D. 1995. Stewardship in the economic and management sciences. Shortened edition. Potchefstroom: Potchefstroom University. [Department of Central Publications.]

DIXON WAG. 1994. Affirmative Action: the perfect excuse or the perfect opportunity. Johannesburg : RAU. [Research study: ABM Certificate].

ENTERPRISE. 2000. Look to NGOs to deliver. Partnerships. Supplement to Enterprise ${ }_{1} 147$, September:1.

HELLRIEGEL D, JACKSON SE \& SLOCUM JW. 1999. Management. Cincinnati: South-Western.

KRUGER S. 1995. New management thinking into the $21^{\text {st }}$ century. Unpublished class notes. Johannesburg: RAU.

MURPHY J. 2000. What can businesses do? A Succeed Magazine Special Publication, August/September:21.

PATON C. 2000. Stop the world: we want to get on. Sunday Times Insight, July 9:1.

SIGONYELA M. 2000. Critical IT skills shortage looms over SA economy. Sunday Times Business Times, July 9:2.

STEYN P. 2000. Vigs gaan gesinne in SA oor tien jaar ekonomies erg knou. Beeld, 12 Julie:12.

SUCCEED. 2000. Handling the impact. A succeed Magazine Special Publication, August/September: 4 -7.

SWANEPOEL T. 2000. HIV/vigs: die grootste ramp in mensegeheugenis. Beeld, 7 Julie:9.

TAITZ L. 2000. Young, gifted and dead. Sunday Times, July 9:1.

TIMMERS GH. 1996. Golwe van verandering: 'n perspektief vir die jaar 2000. Johannesburg: RAU. [M Com (Ondernemingsbestuur) - skripsie].

WHITESIDE A \& SUNTER M. 2000. AIDS: The challenge for South Africa. Sunday Times, July 9:15. 